\title{
PENGARUH MODEL PEMBELAJARAN INQUIRY TRAINING TERHADAP HASIL BELAJAR SISWA PADA MATERI POKOK USAHA DAN ENERGI KELAS VIII MTS N-3 MEDAN
}

\author{
Ratni Sirait \\ Jurusan Pendidikan Fisika \\ Program Pascasarjana Universitas Negeri Medan
}

\begin{abstract}
Abstrak. Penelitian ini bertujuan untuk mengetahui pengaruh model pembelajaran inquiry training terhadap hasil belajar siswa kelas VIII Semester I pada materi pokok Usaha dan Energi di MTs N 3 Medan T.P 2010. Jenis penelitian ini adalah quasi eksperimen. Pengambilan sampel dilakukan dengan cara cluster random sampling dengan mengambil 2 kelas dari 5 kelas secara acak yaitu kelas VIII-D sebagai kelas eksperimen yang berjumlah 34 orang dan kelas VIII-C sebagai kelas kontrol yang berjumlah 36 orang. Hasil analisis data melalui uji t menunjukkan bahwa diperoleh $\mathrm{t}_{\text {hitung }}=1,71$ dan $\mathrm{t}_{\text {tabel }}=1,67$, sehingga $\mathrm{t}_{\text {hitung }}>\mathrm{t}_{\text {tabel }}$, artinya $\mathrm{H}_{\mathrm{a}}$ diterima. Dapat disimpulkan ada pengaruh terhadap hasil belajar siswa dengan menggunakan model pembelajaran inquiry training pada materi pokok usaha dan energi kelas VIII semester I MTs N 3 Medan.
\end{abstract}

Kata kunci: model pembelajaran, inquiry training, hasil belajar

\section{Pendahuluan}

Selama proses pembelajaran, pada umumnya guru jarang mengajak siswa melakukan pengamatan atau praktikum untuk materi yang sedang dipelajari secara nyata. Sebagai gantinya guru melakukan demonstrasi di depan kelas. Demonstrasi dilakukan karena guru memiliki pertimbangan bahwa kegiatan demonstrasi tidak menghabiskan waktu yang banyak dan dapat menyelesaikan materi dengan cepat. Penerapan pembelajaran seperti ini akan mengakibatkan siswa kurang mampu melakukan praktikum, sehingga kemampuan siswa seperti melakukan pengamatan, merumuskan hipotesis, menggunakan alat, mengumpulkan data, mengidentifikasi variabel, membuat kesimpulan dan kegiatan lain yang dapat mengembangkan keterampilan proses ilmiah yang ada pada diri siswa tidak tampak.

Rendahnya hasil belajar Fisika siswa yang ditemukan peneliti saat melaksanakan Program Pengalaman Lapangan Terpadu di
SMA Persiapan, Stabat pada tahun 2009 diakibatkan banyaknya siswa beranggapan bahwa Fisika adalah pelajaran yang sangat sulit dan penerapan rumus-rumus ke dalam soal juga tidak mudah. Selama ini siswa bahkan mengenal Fisika sebagai suatu pelajaran yang sangat menakutkan, salah satu penyebabnya karena pada saat proses pembelajaran Fisika, guru jarang melibatkan siswa dan hanya menekankan siswa untuk menghafal rumus-rumus.

Dari hasil studi pendahuluan di MTs N 3 Medan dengan instrumen angket dan wawancara dapat diperoleh sejumlah data. Dari hasil angket yang disebarkan kepada 38 siswa kelas VIII diperoleh data bahwa 22 orang mengatakan Fisika itu sulit dan kurang menarik, 11 orang mengatakan bahwa pelajaran Fisika itu biasa saja. Sedangkan 5 orang mengatakan Fisika itu mudah dan menyenangkan. Alasan siswa mengatakan bahwa fisika itu sulit dan kurang menarik karena fisika tidak terlepas dari rumusrumus yang harus dihafal. Tetapi ada juga 
Sirait, R.: Pengaruh Model Pembelajaran Inquiry Training Terhadap Hasil Belajar Siswa Pada Materi Pokok Usaha dan Energi Kelas VIII MTs N-3 Medan.

siswa yang sulit dalam pemahaman materi dan soal, sehingga jika soal diubah dalam bentuk lain maka siswa tidak mampu mengerjakannya. (Diperoleh dari hasil wawancara dengan siswa). Melalui angket, diketahui bahwa terdapat perbedaan siswa dalam mengalami peristiwa belajar. Keadaan ini menuntut peserta didik dipenuhi kebutuhan belajarnya sesuai karakteristik masing-masing. Sekitar 22 orang siswa menginginkan belajar dengan praktek dan demonstrasi, 2 orang dengan mengerjakan soalsoal, dan 14 mengatakan bahwa belajar Fisika itu sambil bermain. Fisika menempati posisi yang kedua setelah matematika sebagai pelajaran yang kurang digemari.

Dari hasil wawancara dengan salah seorang Guru Fisika di MTs N 3 Medan mengatakan bahwa bila siswa diajarkan secara teori, maka minat siswa terhadap Fisika sangat kurang. Sedangkan bila siswa diajak ke laboratorium akan muncul minat siswa terhadap Fisika. Menurut Joyce (2009) model pembelajaran inquiry training dirancang untuk membawa siswa secara langsung ke dalam proses ilmiah melalui latihan-latihan yang dapat memadatkan proses ilmiah tersebut ke dalam periode waktu yang singkat. Tujuannya adalah membantu siswa mengembangkan disiplin dan mengembangkan keterampilan intelektual yang diperlukan untuk mengajukan pertanyaan dan menemukan jawabannya berdasarkan rasa ingin tahunya.

Perbedaan peneliti sebelumnya dengan peneliti sekarang adalah terletak pada fase model pembelajaran inquiry training di Rencana Pelaksanaan Pembelajaran (RPP). Peneliti sebelumnya masih menggunakan fase inkuiri biasa sedangkan peneliti sekarang menggunakan fase inquiry training.

Dari hasil investigasi awal sesuai latar belakang, dapat diidentifikasi beberapa masalah, yaitu (1) Hasil belajar siswa pada mata pelajaran Fisika masih rendah, (2) Perbedaan individu siswa dalam mengalami peristiwa belajar, (3) Proses pembelajaran lebih memfokuskan pada rumus-rumus dan dalil, (4) Guru belum menerapkan model pembelajaran yang
Jurnal Pendidikan Fisika

p-ISSN 2252-732X

$e-I S S N 2301-7651$

bervariasi. Untuk itu perlu adanya pembatasan masalah yang memfokuskan pada (1) Menerapkan model pembelajaran inquiry training di kelas eksperimen, (2) Materi pelajaran yang diajarkan adalah Usaha dan Energi, (3) Hasil belajar yang akan diteliti hanya pada aspek kognitif yang disertai pengamatan aktivitas.

Berdasarkan latar belakang, identifikasi dan batasan masalah, rumusan masalah dalam penelitian ini adalah (1) Bagaimana hasil belajar siswa dengan menggunakan model pembelajaran inquiry training pada materi pokok usaha dan energi kelas VIII semester I MTs N 3 Medan? (2) Bagaimana aktivitas belajar siswa kelas VIII selama pelaksanaan model pembelajaran inquiry training? (3) Apakah ada pengaruh model pembelajaran inquiry training terhadap hasil belajar siswa pada materi pokok usaha dan energi kelas VIII semester I MTs N 3 Medan? Sedangkan tujuannya adalah untuk (1) mengetahui hasil belajar siswa dengan menggunakan model pembelajaran inquiry training pada materi pokok usaha dan energi kelas VIII semester I MTs N 3 Medan, (2) mengetahui aktivitas belajar siswa kelas VIII selama pelaksanaan pembelajaran dengan model pembelajaran inquiry training, (3) mengetahui pengaruh model pembelajaran inquiry training terhadap hasil belajar siswa pada materi pokok usaha dan energi kelas VIII semester I MTs N 3 Medan.

\section{Model Pembelajaran Inkuiri}

Inkuiri adalah proses pembelajaran didasarkan pada pencarian dan penemuan melalui proses berpikir secara sistematis. Pengetahuan bukanlah sejumlah fakta hasil dari mengingat, akan tetapi hasil dari proses menemukan sendiri. Dengan demikian dalam proses perencanaan, guru bukanlah mempersiapkan sejumlah materi yang harus di hafal, akan tetapi merancang pembelajaran yang memungkinkan siswa dapat menemukan sendiri materi yang harus di pahaminya. Belajar pada dasarnya merupakan proses mental seseorang yang tidak terjadi secara mekanis. Gulo dalam Trianto (2009) menyatakan bahwa inkuiri tidak 
Sirait, R.: Pengaruh Model Pembelajaran Inquiry Training Terhadap Hasil Belajar Siswa Pada Materi Pokok Usaha dan Energi Kelas VIII MTs N-3 Medan.

hanya mengembangkan kemampuan intelektual tetapi seluruh potensi yang ada, termasuk pengembangan emosional dan keterampilan inkuiri merupakan suatu proses yang bermula dari merumuskan masalah, merumuskan hipotesis, mengumpulkan data, menganalisis data, dan membuat kesimpulan

\section{Model Pembelajaran Inquiry Training}

Model pembelajaran inquiry training dikembangkan oleh seorang tokoh yang bernama Suchman (1962). Suchman meyakini bahwa anak-anak merupakan individu yang penuh rasa ingin tahu akan segala sesuatu. Model pembelajaran inquiry training dirancang untuk membawa siswa secara langsung ke dalam proses ilmiah melalui latihan-latihan yang dapat memadatkan proses ilmiah tersebut ke dalam periode waktu yang singkat. Pengaruhnya adalah bahwa model pembelajaran inquiry training (latihan penelitian) akan meningkatkan pemahaman ilmu pengetahuan, produktivitas dalam berpikir kreatif, dan keterampilanketerampilan dalam memperoleh dan menganalisis informasi, tetapi latihan ini seefisien metode pengulangan dan pengajaran yang dibarengi dengan pengalaman-pengalaman laboratorium.

Model pembelajaran inquiry training adalah upaya pengembangan para pembelajar yang mandiri, metodenya mensyaratkan partisipasi aktif siswa dalam penelitian ilmiah. Siswa sebenarnya memiliki rasa ingin tahu dan hasrat yang besar untuk tumbuh berkembang. Model pembelajaran inquiry training memanfaatkan eksplorasi kegairahan alami siswa, memberikan siswa arahan-arahan khusus sehingga siswa dapat mengeksplorasi bidangbidang baru secara efektif.

Tujuan umum model pembelajaran inquiry training adalah membantu siswa mengembangkan disiplin intelektual dan keterampilan untuk meningkatkan pertanyaanpertanyaan dan pencarian jawaban yang terpendam dari rasa keingintahuan siswa. Untuk itulah, Suchman tertarik untuk membantu siswa meneliti secara mandiri, tetapi dalam cara
Jurnal Pendidikan Fisika

p-ISSN 2252-732X

e-ISSN2301-7651

yang disiplin. Suchman ingin siswa-siswanya bertanya mengapa sesuatu peristiwa tertentu harus terjadi seperti itu, ada apa sebenarnya, bagaimana saya bisa menyelidikinya. Suchman juga ingin siswanya memperoleh dan memproses data secara logis dengan mengembangkan strategi-strategi intelektual umum yang dapat siswa gunakan untuk mencari tahu terjadinya fenomena atau peristiwa tertentu.

Model pembelajaran inquiry training memiliki lima tahap pembelajaran, yaitu: Fase I: Menghadapkan pada masalah. Menghadapkan siswa dengan situasi yang membingungkan (masalah). Fase II: Merumuskan hipotesis. Mengajukan pertanyaan dimana pertanyaan tersebut sudah mengandung jawaban. Fase III: Pengumpulan data-eksperimentasi. Memisahkan variabel yang relevan. Menghipotesiskan (serta menguji) hubungan kausal. Fase IV: Mengolah, memformulasikan suatu penjelasan. Memformulasikan aturan dan penjelasan. Fase $\boldsymbol{V}$ : Analisis proses penelitian. Menganalisis strategi penelitian dan mengembangkan yang paling efektif.

\section{Metode Penelitian}

Penelitian ini dilaksanakan di MTs N 3 Medan yang beralamat di Jalan Melati 13 Helvetia. Penelitian ini berlangsung selama tiga minggu yang dimulai dari tanggal 13 Juli 2010 sampai 2 Agustus 2010. Populasi dalam penelitian ini adalah seluruh siswa kelas VIII semester I MTs N 3 Medan yang terdiri dari 5 kelas. Pengambilan sampel dilakukan secara acak (cluster random sampling) dimana setiap kelas memiliki kesempatan yang sama untuk menjadi sampel penelitian. Sampel yang diambil sebanyak dua kelas yaitu VIII-D sebagai kelas eksperimen dan VIII-C sebagai kelas kontrol. Penelitian ini termasuk jenis penelitian quasi eksperimen, yaitu merupakan penelitian yang bertujuan untuk mengetahui akibat dari "sesuatu" yang dikenakan pada "subyek" yaitu siswa. Penelitian ini melibatkan dua kelas sampel yang diberi perlakuan yang berbeda. Untuk mengetahui hasil belajar Fisika, siswa akan diberikan tes. Tes yang dilakukan 
yaitu pretes (sebelum diberi perlakuan) dan postes (setelah diberi perlakuan). Desain penelitiannya berupa The pretest-postest Control Group Design sebagai berikut:

Tabel 1. Desain Penelitian

\begin{tabular}{|l|c|c|c|}
\hline \multicolumn{1}{|c|}{ Sampel } & Pretes & Perlakuan & Postes \\
\hline Kelas Eksperimen & $\mathrm{T}$ & $\mathrm{X}$ & $\mathrm{T}$ \\
\hline Kelas Kontrol & $\mathrm{T}$ & $\mathrm{Y}$ & $\mathrm{T}$ \\
\hline
\end{tabular}

Keterangan:

$\mathrm{T}=$ pre test dan post test

$\mathrm{X}=$ perlakuan (treatment) untuk model

pembelajaran inquiry training

$\mathrm{Y}=$ perlakuan (treatment) untuk model pembelajaran konvensional

Data-data yang diperoleh diuji normalitasnya untuk mengetahui apakah data kedua sampel berdistribusi normal atau tidak. Uji normalitas data digunakan uji Liliefors. Kemudian dilakukan uji homogenitas berfungsi untuk mengetahui apakah kedua sampel berasal dari populasi yang homogen. Menurut Sudjana (2005), untuk uji homogenitas data populasi digunakan uji kesamaan varians, dengan rumus.

$$
F=\frac{S_{1}^{2}}{S_{2}^{2}}
$$

Dimana: $S_{1}{ }^{2}=$ Varians terbesar; $S_{2}{ }^{2}=$ Varians terkecil. Kriteria Pengujian: Jika $F_{\text {hitung }}>F_{\text {tabel }}$, maka kedua sampel tidak berasal dari populasi yang homogen dan sebaliknya pada taraf Signifikan $(\alpha)=0,05$.

Untuk uji hipotesis digunakan uji $t$ dengan rumus:

$$
\mathrm{t}=\frac{\bar{X}_{1}-\bar{X}_{2}}{s \sqrt{\frac{1}{n_{1}}+\frac{1}{n_{2}}}} \quad \text { (Sudjana, 2005) }
$$

dengan standar deviasi gabungan:

$$
S^{2}=\frac{\left(n_{1}-1\right) S_{1}^{2}+\left(n_{2}-1\right) S_{2}^{2}}{n_{1}+n_{2}-2}
$$

Dimana:

$\overline{\mathrm{X}}_{1}=$ nilai rata-rata hasil belajar siswa kelas eksperimen.

$\overline{\mathrm{X}}_{2}=$ nilai rata-rata hasil belajar siswa kelas kontrol. $\mathrm{n}_{1}=$ jumlah siswa kelas eksperimen.

$\mathrm{n}_{2}=$ jumlah siswa kelas kontrol.

$S_{1}^{2}=$ varians nilai hasil belajar siswa kelas eksperimen.

$S_{2}^{2}=$ varians nilai hasil belajar siswa kelas kontrol.

Kriteria pengujian: $\mathrm{H}_{\mathrm{o}}$ diterima jika $-\mathrm{t}_{(1-\alpha)}<\mathrm{t}_{(1-}$ a) dimana $t_{(1-\alpha)}$ di dapat dari daftar distribusi $t$ dengan $\mathrm{dk}=\left(\mathrm{n}_{1}+\mathrm{n}_{2}-2\right)$ dan peluang $(1-\alpha)$ dan $\alpha=0,05$. Untuk harga t lainnya $\mathrm{H}_{\mathrm{o}}$ ditolak.

\section{Hasil Penelitian dan Pembahasan Hasil Penelitian}

Penerapan model pembelajaran inquiry training ini didasarkan atas kelebihannya yang menekankan kepada pengembangan aspek kognitif dan aspek psikomotorik secara seimbang, sehingga pembelajaran melalui model ini dianggap lebih bermakna. Dalam proses model pembelajaran inquiry training ini, dilibatkan sejumlah pengalaman siswa dalam kehidupan sehari-hari yang terkait dengan usaha dan energi.

Penelitian kuasi eksperimen ini melibatkan serangkaian kegiatan model pembelajaran inquiry training yang meliputi: menghadapkan siswa pada masalah, merumuskan hipotesis, pengumpulan data eksperimen, mengolah dan menganalisis proses penelitian, merupakan serangkaian kegiatan yang dapat memicu kegiatan belajar siswa.

Dari hasil pretes yang diberikan kepada kedua sampel diperoleh nilai rata-rata kelas eksperimen 4,29 dan pada kelas control 4,03. Setelah dilakukan pretes, di kelas eksperimen diberi perlakuan model pembelajaran inquiry training dan di kelas kontrol diberi perlakuan berupa model pembelajaran konvensional. Dari kedua perlakuan ini, kemudian dilakukan postes dan diperoleh sejumlah pengetahuan yang hasilnya adalah nilai rata-rata kelas eksperimen 6,29 dan pada kelas kontrol 5,64.

Berdasarkan hasil uji normalitas data menggunakan uji Lilliefors dari data pretes dan postes kelas eksperimen dan kelas kontrol diperoleh untuk data pretes kelas eksperimen $\mathrm{L}_{\text {hitung }}<\mathrm{L}_{\text {tabel }}(0,1459<0,1520)$ sedangkan 
Sirait, R.: Pengaruh Model Pembelajaran Inquiry Training Terhadap Hasil Belajar Siswa Pada Materi Pokok Usaha dan Energi Kelas VIII MTs N-3 Medan.

untuk kelas kontrol $\mathrm{L}_{\text {hitung }}<\mathrm{L}_{\text {tabel }}(0,1438<$ $0,1477)$. Data postes kelas eksperimen $\mathrm{L}_{\text {hitung }}<$ $\mathrm{L}_{\text {tabel }}(0,1302<0,1520)$ dan kelas kontrol $\mathrm{L}_{\text {hitung }}$ $<\mathrm{L}_{\text {tabel }}(0,1276<0,1477)$. Ini berarti data pretes dan postes untuk berdistribusi normal untuk taraf signifikan $\alpha=0,05$.

Uji homogenitas menggunakan uji $\mathrm{F}$ dari data pretes dan postes kelas eksperimen dan kelas kontrol. Uji homogenitas dimaksudkan untuk mengetahui apakah kedua sampel berasal dari populasi yang homogen atau tidak. Ternyata untuk data pretes $\mathrm{F}_{\text {hitung }}<\mathrm{F}_{\text {tabel }}(1,26<$ $1,79)$ dan untuk data postes $F_{\text {hitung }}<F_{\text {tabel }}(1,00$ $<1,79)$. Ini berarti varians kedua sampel homogen pada taraf signifikan $\alpha=0,05$.

Uji hipotesis menggunakan uji $t$, dimaksudkan untuk melihat perbedaan hasil belajar di kelas eksperimen dan kelas kontrol akibat pengaruh model pembelajaran inquiry training. Syarat uji $\mathrm{t}$ ini adalah data harus berdistribusi normal dan sampel harus berasal dari populasi yang homogen. Melihat kedua syarat tersebut telah terpenuhi, berikut ini disajikan ringkasan perhitungan dengan uji t, dengan $\alpha=0,05$ dari data postes. Dari hasil perhitungan diperoleh $\mathrm{t}_{\text {hitung }}=1,71$ dan $\mathrm{t}_{\text {tabel }}=$ 1,67 sehingga $t_{\text {hitung }}>t_{\text {tabel }}$, berarti terima $\mathrm{H}_{a}$ dan tolak $\mathrm{H}_{\mathrm{o}}$. Sehingga dapat disimpulkan bahwa terdapat pengaruh yang signifikan terhadap hasil belajar siswa yang diajarkan dengan menerapkan model pembelajaran inquiry training pada materi pokok usaha dan energi di kelas VIII semester I MTs N.3 Medan.

\section{Pembahasan}

Hasil penelitian menunjukkan bahwa ada pengaruh yang signifikan menggunakan model pembelajaran inquiry training terhadap hasil belajar siswa pada materi pokok usaha dan energi kelas VIII semester I MTs N 3 Medan T.P 2010/2011. Hal ini diperkuat dengan perolehan nilai rata-rata pretes siswa dikelas eksperimen sebesar 4,29 dengan standar deviasi 1,32 dan nilai rata-rata postes sebesar 6,29 dengan standar deviasi 1,58. Sedangkan di kelas kontrol diperoleh nilai rata-rata pretes
Jurnal Pendidikan Fisika

p-ISSN 2252-732X

e-ISSN2301-7651

siswa sebesar 4,03 dengan standar deviasi 1,48 dan nilai rata-rata postes sebesar 5,64 dengan standar deviasi 1,59.

Selama pelaksanaan penelitian diperoleh bahwa model pembelajaran inquiry training menguntungkan karena memberi peluang yang sama kepada semua siswa, baik siswa yang memiliki kemampuan rendah, sedang ataupun tinggi untuk berhasil. Oleh karena itu, siswa yang berkemampuan rendah, sedang maupun tinggi semuanya ditantang untuk dapat menemukan materi melalui praktikum dengan bantuan bimbingan dari peneliti.

Model pembelajaran inquiry training mengajarkan siswa untuk lebih berani berbicara di depan kelas. Masing-masing kelompok tidak ingin mau kalah dengan kelompok lain untuk maju kedepan menyimpulkan materi pelajaran. Ini terlihat pada saat siswa dalam setiap kelompok berebut untuk menyimpulkan hasil praktikumnya di depan kelas.

Pada dasarnya, tujuan utama penelitian ini adalah untuk mengetahui pengaruh model pembelajaran inquiry training terhadap hasil belajar siswa. Namun, tugas yang diberikan kepada setiap kelompok berupa lembar aktivitas maka perlu dilakukan pencatatan terhadap aktivitas siswa selama kegiatan pembelajaran. Pencatatan terhadap aktivitas siswa ini bertujuan untuk mengetahui seberapa besar keaktifan siswa selama pembelajaran berlangsung.

Walaupun penggunaan model pembelajaran inquiry trining dapat meningkatkan hasil belajar dan aktivitas siswa, tetapi selama pembelajaran masih ada kendala yang dihadapi peneliti yaitu, kurang pahamnya siswa membuat pertanyaan yang harus mengandung jawaban "ya" atau "tidak". Oleh sebab itu upaya yang dilakukan adalah agar peneliti mampu menyampaikan kepada siswa jenis pertanyaan yang digunakan dalam pembelajaran.

Selain itu, kesulitan yang dihadapi peneliti yaitu adanya siswa yang tidak serius di setiap kelompok pada saat praktikum karena banyaknya siswa di setiap kelompok mengakibatkan adaya keributan dan kurang aktifnya siswa di setiap kelompok. Untuk mengatasi hal 
Sirait, R.: Pengaruh Model Pembelajaran Inquiry Training Terhadap Hasil Belajar Siswa Pada Materi Pokok Usaha dan Energi Kelas VIII MTs N-3 Medan.

ini, upaya yang dilakukan adalah sebaiknya jumlah siswa dalam setiap kelompok cukup 2-3 orang saja agar semua siswa bekerja dalam setiap kelompok.

\section{Simpulan}

Dari hasil analisis data yang dilakukan dapat ditarik kesimpulan (1) Hasil belajar siswa menggunakan model pembelajaran inquiry training pada materi pokok usaha dan energi kelas VIII MTs N 3 Medan memiliki rata-rata 6,29 dan hasil belajar siswa menggunakan model pembelajaran konvensional pada materi pokok usaha dan energi memiliki rata-rata 5,64. (2) Hasil observasi aktivitas belajar siswa di kelas eksperimen dengan menggunakan model pembelajaran inquiry training diperoleh skor
Jurnal Pendidikan Fisika

p-ISSN 2252-732X

e-ISSN2301-7651

67,38 dengan kategori aktif. (3) Berdasarkan hasil perhitungan uji $\mathrm{t}$ diperoleh bahwa ada pengaruh menggunakan model pembelajaran inquiry training pada materi pokok usaha dan energi kelas VIII semester I MTs N 3 Medan T.P 2010/2011.

\section{Daftar Pustaka}

Joyce, B. \& Weil, M. 2009. Model-Model Pembelajaran. Edisi Delapan. Yogyakarta: Pustaka Pelajar.

Sudjana. 2005. Metode Statistik. Bandung: Tarsito.

Trianto. 2009. Model-Model Pembelajaran Inovatif Berorientasi Konstruktivistik. Jakarta: Prestasi Pustaka. 